\title{
Shining light on sentinel node assessment for lung cancer: Quality is superior to quantity
}

\author{
Daniela Molena, MD
}

\author{
From the Division of Thoracic Surgery, Department of Surgery, Memorial Sloan Kettering Cancer Center, \\ New York, NY. \\ Disclosures: Author has nothing to disclose with regard to commercial support. \\ Received for publication Oct 4, 2017; accepted for publication Oct 9, 2017; available ahead of print Nov 15, 2017. \\ Address for reprints: Daniela Molena, MD, Thoracic Surgery Service, Department of Surgery, Memorial Sloan \\ Kettering Cancer Center, 1275 York Ave, New York, NY 10065 (E-mail: molenad@mskcc.org). \\ J Thorac Cardiovasc Surg 2018;155:1292-3 \\ $0022-5223 / \$ 36.00$ \\ Copyright (c) 2017 by The American Association for Thoracic Surgery \\ https://doi.org/10.1016/j.jtcvs.2017.10.013
}

The introduction of intraoperative lymphatic mapping 25 years ago ${ }^{1}$ significantly changed the surgical approach to breast cancer, melanoma, and gynecologic cancer. There is no reason to believe that lung cancer behaves differently from other solid malignancies for which Halsted's theory of sequential dissemination ${ }^{2}$ has been confirmed, and, as a result, the role of the sentinel node as the first node involved by metastatic cancer cells has been extensively validated. ${ }^{3}$ In fact, the 2 main controversial and current subjects of debate among the thoracic surgical community indirectly support this concept and stress the importance of the study conductthe extension of mediastinal nodal dissection for early-stage lung cancer. There is no doubt that nodal metastasis is an important prognostic factor in the treatment of the disease, and the results of the American College of Surgery Oncology Group Z0030 trial $^{5}$ left us unsatisfied. The high reported rate of pathologic upstaging ${ }^{6}$ after resection of early-stage lung cancer confirms that preoperative testing is often inaccurate for mediastinal staging and that "blinded" nodal sampling may not fare much better. ${ }^{7}$ Efforts that target either nodal sampling (with negative sentinel nodes) or dissection (for positive sentinel nodes) therefore make a lot of sense and leave one wondering why such uncertainty with mediastinal assessment has been accepted for so long. The second controversy regards the never-ending debate about lobectomy versus sublobar resection. ${ }^{8}$ As with breast cancer, if we had a better understanding of the patterns of drainage of lung cancer within the lung parenchyma and the segmental anatomy, we would not be dwelling on lung sparing. It is the threat of recurrence, perhaps as a result of unforeseen lymphatic spread, that has reinforced the belief that resecting more lung parenchyma is better, even for small tumors. Being able to identify the lymphatic basin and sentinel nodes of a lung cancer thus should give us confidence about the appropriate extension of resection.

I therefore read with enthusiasm the pilot study by Hachey and colleagues ${ }^{4}$ about near-infrared localization of sentinel lymph nodes in lung cancer. Hachey and ed by Hachey and colleagues. ${ }^{4}$ The first controversy regards

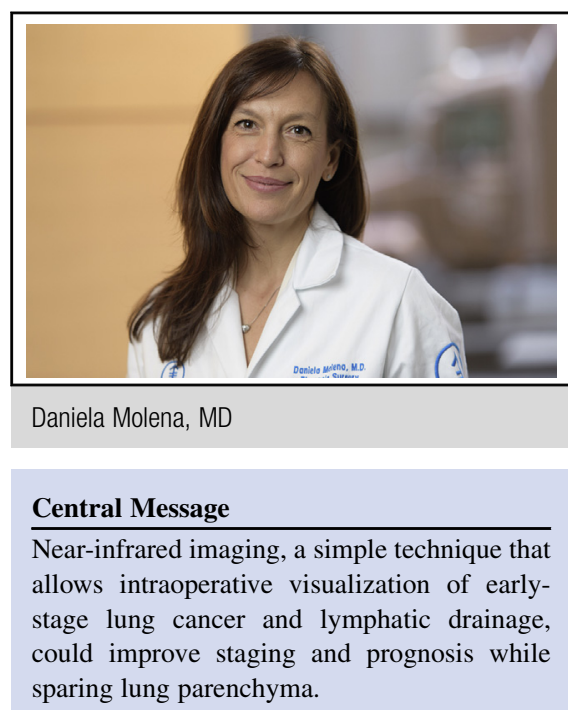

See Article page 1280. colleagues ${ }^{4}$ demonstrate an easy technique that can be used not only to localize small lung nodules but also to map their lymphatic drainage. The potential advantages of this approach are exciting. First and foremost, I see the opportunity to use a targeted approach for lung cancer surgery. Moreover, by directing resection to the areas that most likely harbor disease, we have the opportunity to improve staging and potentially increase survival. It is encouraging, in fact, that patients with pathologically negative sentinel nodes identified with near-infrared technology had improved survival relative to patients with negative nodes identified with standard mediastinal staging. This finding supports the hypothesis that intraoperative guidance may help thoracic surgeons perform better resections, improve patient selection for adjuvant therapy, and finally improve the prognosis of early-stage lung cancer.

Although this is only a pilot study involving few patients, the results are encouraging enough that a larger trial is highly anticipated. In the era of precision medicine, we have the opportunity to demonstrate again that surgical quality is superior to quantity.

\section{References}

1. Morton DL, Wen DR, Wong JH, Economou JS, Cagle LA, Storm FK, et al. Technical details of intraoperative lymphatic mapping for early stage melanoma. Arch Surg. 1992;127:392-9.

2. Halsted WS. I. The results of operations for the cure of cancer of the breast performed at the Johns Hopkins Hospital from June, 1889, to January, 1894. Ann Surg. 1894;20:497-555. 
3. Turner RR, Ollila DW, Krasne DL, Giuliano AE. Histopathologic validation of the sentinel lymph node hypothesis for breast carcinoma. Ann Surg. 1997;226:271-6; discussion 276-278.

4. Hachey KJ, Digesu CS, Armstrong KW, Gilmore DM, Khullar OV, Whang B, et al. A novel technique for tumor localization and targeted lymphatic mapping in earlystage lung cancer. J Thorac Cardiovasc Surg. 2017;154:1110-8.

5. Darling GE, Allen MS, Decker PA, Ballman K, Malthaner RA, Inculet RI, et al. Randomized trial of mediastinal lymph node sampling versus complete lymphadenectomy during pulmonary resection in the patient with N0 or N1 (less than hilar) non-small cell carcinoma: results of the American College of Surgery Oncology Group Z0030 Trial. J Thorac Cardiovasc Surg. 2011;141:662-70.
6. Medbery RL, Gillespie TW, Liu Y, Nickleach DC, Lipscomb J, Sancheti MS, et al Nodal upstaging is more common with thoracotomy than with VATS during lobectomy for early-stage lung cancer: an analysis from the National Cancer Data Base. J Thorac Oncol. 2016;11:222-33.

7. Varlotto JM, Recht A, Nikolov M, Flickinger JC, Decamp MM. Extent of lymphadenectomy and outcome for patients with stage I nonsmall cell lung cancer. Cancer. 2009;115:851-8.

8. Altorki NK, Yip R, Hanaoka T, Bauer T, Aye R, Kohman L, et al. Sublobar resection is equivalent to lobectomy for clinical stage $1 \mathrm{~A}$ lung cancer in solid nodules. J Thorac Cardiovasc Surg. 2014;147:754-62; discussion 762-764. 